\title{
Generation of Functional Inhibitory Neurons in the Adult Rat Hippocampus
}

\author{
ShuHong Liu, Jian Wang, DongYa Zhu, YangPing Fu, Ken Lukowiak, and YouMing Lu \\ Neuroscience Research Group, Department of Physiology and Biophysics, Faculty of Medicine, University of Calgary, Calgary, Alberta, Canada, T2N 4N1
}

Several thousand new neurons are produced each day in the adult mammalian hippocampus, among which only excitatory granule cells (GCs) have thus far been identified. In the present study, we used mutant Semliki Forest Virus vectors to express enhanced green fluorescent protein in the hippocampus, and observed that $\sim 14 \%$ of newly generated neurons in the dentate gyrus of adult rats are GABAergic basket cells (BCs). With the use of double whole-cell patch-clamp recordings from BC-GC pairs in hippocampal slices, we demonstrate that newly generated $\mathrm{BCs}$ in the dentate gyrus form inhibitory synapses with principal GCs. These data show for the first time that functional inhibitory neurons are recruited in the dentate gyrus of adult rats.

Key words: neurogenesis; functional inhibitory neurons; GABAergic interneurons; virus vectors; green fluorescent protein; adult rat dentate gyrus

\section{Introduction}

There is extensive evidence showing that new neurons are added to the dentate gyrus of adults in many species of vertebrates (Kaplan and Hinds, 1977; Eriksson et al., 1998; Gould et al., 1999; Kornack and Rakic, 1999). However, only new excitatory granule cells (GCs) have been identified to date (Paton and Nottebohm, 1984; Markakis and Gage, 1999; Cameron and McKay, 2001; van Praag et al., 2002). It is unknown whether inhibitory neurons are also newly recruited in the adult dentate gyrus. The inability to identify newly generated inhibitory neurons in situ is primarily attributable to the limitations of the conventional methods used in studying neurogenesis. For example, double-staining sections with 5-bromodeoxyuridine (BrdU) and a mature neuronal marker [neuronalspecific nuclear protein (NeuN)] labels nerve cell nuclei, and thus does not allow morphological analysis of cell type.

There has been much anticipation of breaking through this barrier by using a retroviral vector expressing green fluorescent protein (GFP) (Song et al., 2002; van Praag et al., 2002). For example, a retroviral vector expressing GFP in dividing cells can be visualized using fluorescence microscopy, allowing physiological recordings from newly generated GCs (Song et al., 2002; van Praag et al., 2002). Unfortunately, only a relatively low infection rate can be achieved with the previously used retroviral vectors (Miller et al., 1990), making it difficult to functionally characterize newly added neuronal subsets (e.g., inhibitory GABAergic neurons). To overcome this problem, we used mutant Semliki Forest Virus $[\mathrm{pSFV}(p d)]$ vectors, which efficiently introduced

Received Sept. 12, 2002; revised Nov. 18, 2002; accepted Nov. 20, 2002

This work was supported by grants from the Canadian Institutes of Health Research (Y.L.), Heart and Stroke Foundation, Canada (Y.L.), Alberta Heritage Foundation for Medical Research (Y.L.), Canada Foundation for Innovation (Y.L.), and Alberta Foundation of Innovation and Science (Y.L.). We thank Drs. Keith Sharkey and Brian MacVicar for critical comments on this manuscript. We also thank Drs. Quentin Pittman and Jaideep Bains for their help with stereotaxic work.

Correspondence should be addressed to Dr. YouMing Lu at the above address. E-mail: luy@ucalgary.ca. Copyright $\odot 2003$ Society for Neuroscience $\quad 0270-6474 / 03 / 230732-05 \$ 15.00 / 0$ enhanced GFP into neurons in the hippocampus, allowing morphological and functional analysis of newly generated cell types.

\section{Materials and Methods}

Animals. Sprague Dawley rats (50\% female and 50\% male) from the breeding colony at the University of Calgary were used in this study. These animals were divided into three groups. In group 1, 10-week-old rats were injected with $\mathrm{BrdU}$ (100 mg/kg body weight, i.p.) on 3 consecutive days at $24 \mathrm{hr}$ intervals and killed $6 \mathrm{~d}$ (group 1a) or 8 weeks (group 1b) after the last BrdU injection. These rats were not infused with $\operatorname{pSFV}(p d)-\mathrm{GFP}$ virus vector, and their hippocampi were processed for immunostaining. In group 2, 10-week-old rats were injected with BrdU on 3 consecutive days at $24 \mathrm{hr}$ intervals and then had the $\operatorname{pSFV}(p d)-\mathrm{GFP}$ virus vectors infused $6 \mathrm{~d}$ after the last BrdU injection. In group 3, 8-weekold rats were injected with BrdU on 3 consecutive days at 24 hr intervals and had the pSFV $(p d)-G F P$ virus vectors infused 6 weeks after the last BrdU injection. This group of animals was used for electrophysiological recording.

For $\mathrm{pSFV}(p d)-\mathrm{GFP}$ virus vector infection, animals were anesthetized (100 $\mu \mathrm{g}$ of ketamine, $10 \mu \mathrm{g}$ of xylazine in $10 \mu \mathrm{l}$ of saline per gram). Activated pSFV $(p d)-$ GFP virus particles were bilaterally infused $(2 \mu \mathrm{l}$ at $0.2 \mu \mathrm{l} / \mathrm{min}$ ) into the hippocampus, $2 \mathrm{~mm}$ posterior to bregma, $1.5 \mathrm{~mm}$ lateral to the midline, and $2 \mathrm{~mm}$ below dura. At $48 \mathrm{hr}$ after the infusion, animals were anesthetized (Nembutal) and then either fixed with 4\% paraformaldehyde in $0.1 \mathrm{~m}$ phosphate buffer for immunostaining or prepared for electrophysiological recordings.

Construction of $p S F V(p d)-G F P$ vectors and packaging of the recombinant virions. To obtain nontoxic virus vectors with high infection rate, we generated a mutant form of pSFV1 vectors, as reported previously (Lundstrom et al., 1999, 2001). The SacI-XbaI fragment from pSFV1 (Invitrogen, Carlsbad, CA) was subcloned into the pGEM7Zf ${ }^{+}$vector (Promega, Madison, WI). A PCR-based site-directed mutagenesis was used to change Ser $_{259}$ to Pro and Arg $_{650}$ to Asp in the nsP2 fragment. Subsequently, the original fragments in pSFV1 were replaced by the mutated fragments to obtain $\operatorname{pSFV}(p d)$ vectors. Mutations were confirmed by sequencing. A cDNA encoding enhanced GFP (Clontech, Palo Alto, $\mathrm{CA})$ was then inserted directly into $\operatorname{pSFV}(p d)$ vector to produce $\mathrm{pSFV}(p d)-\mathrm{GFP}$ constructs. In vitro transcribed RNA molecules from 
$\operatorname{pSFV}(p d)$-GFP were cotransfected with pSFV-helper2 RNA (a gift from Markus U. Ehrengruber, University of Zurich, Zurich, Switzerland) into baby hamster kidney (BHK)-21 cells. All virus production was performed at $31^{\circ} \mathrm{C}$. At $24 \mathrm{hr}$ after electroporation, virus stocks were harvested, filter sterilized, and activated with chymotrypsin A4 (Invitrogen). The reaction was terminated with the trypsin inhibitor aprotinin (Invitrogen) before use. Final virus titers $\left(\geq 10^{9}\right.$ infectious units $\left./ \mathrm{ml}\right)$ were determined by infection of BHK-21 cells with serial dilutions of virus stocks, followed by fluorescence microscopy examination $3 \mathrm{~d}$ after infection.

Immunocytochemistry. Immunostaining was performed on $40 \mu \mathrm{m}$ free-floating coronal sections. We applied antibodies in $0.1 \mathrm{M}$ TBS with $3 \%$ goat serum and $0.3 \%$ Triton X-100. For BrdU staining, sections were heated $\left(85^{\circ} \mathrm{C}\right.$ for $\left.5 \mathrm{~min}\right)$ in antigen unmasking solution (Vector Laboratories, Burlingame, $\mathrm{CA}$ ), incubated in $2 \mathrm{M} \mathrm{HCl}$ (room temperature for 30 $\mathrm{min}$ ), and blocked in 3\% normal goat serum (room temperature for 1 hr), followed by incubation with rat monoclonal anti-BrdU (1:200; Accurate Chemical, Westbury, NY). Subsequently, the sections were incubated in affinity-purified conjugate-adsorbed second antibody, goat anti-rat Cy3 (1:200; Chemicon, Temecula, CA). These sections were then incubated in one of the following primary antibodies: mouse anti-NeuN (1:100; Chemicon), rabbit anti-Unc-33-like phosphoprotein/collapsing response mediator protein-4 (TUC-4) (1:1000; Chemicon), mouse anti$\mathrm{GAD}_{65}$ (1:1000; Chemicon); mouse anti-parvalbumin (PAV) (1:1000; Sigma, St. Louis, MO), rabbit anti-calretinin (CAL) (1:1000; Chemicon), or rabbit anti-cholecystokinin octapeptide (CCK) (1:500; Chemicon), and reacted with either conjugate-adsorbed goat anti-mouse Cy5 (1:100; Chemicon), or conjugate-adsorbed goat anti-rabbit fluorescein (1:50; Chemicon). Sections were rinsed, dried, and coverslipped with Dako (Glostrup, Denmark) fluorescence mounting medium. Control sections were processed with omission of the primary antisera.

GFP expression and colabeling were viewed and counted with an Olympus (Tokyo, Japan) IX70 fluorescence microscope. Double or triple labeling was imaged with a confocal laser-scanning microscope (Olympus LSM-GB200) and analyzed with a three-dimensional (3D) constructor (Image-Pro Plus software). We produced 3D digital reconstructions from a series of confocal images taken at $0.5 \mu \mathrm{m}$ intervals through the region of interest, and optical stacks of 6-12 images were produced for the figures. We quantified the absolute numbers of $\mathrm{GFP}^{+}-\mathrm{BrdU}^{+}$, $\mathrm{GFP}^{+}-\mathrm{BrdU}^{+}-\mathrm{TUC}-4^{+}, \mathrm{GFP}^{+}-\mathrm{BrdU}^{+}-\mathrm{GAD}_{65}{ }^{+}, \mathrm{GAD}_{65}{ }^{+}-\mathrm{BrdU}^{+}{ }_{-}$ TUC- $4^{+}$, and $\mathrm{BrdU}{ }^{+}-\mathrm{PAV}^{+}$neurons in the dentate gyrus by sampling every section from the experimental animals.

Electrophysiology. Double whole-cell patch-clamp recordings were made from hippocampal slices, as described previously (Lu et al., 2000). Briefly, rats from group 2 and group 3 were anesthetized and decapitated. Slices in the recording chamber were continuously superfused with artificial CSF (ACSF) $\left(2 \mathrm{ml} / \mathrm{min}\right.$ ), saturated with $95 \% \mathrm{O}_{2} / 5 \% \mathrm{CO}_{2}$ at $30^{\circ} \mathrm{C} \pm$ $1^{\circ} \mathrm{C}$. The composition of ACSF (in $\mathrm{mm}$ ) was $124 \mathrm{NaCl}, 3 \mathrm{KCl}, 1.25$ $\mathrm{NaH}_{2} \mathrm{PO}_{4}, 4 \mathrm{MgCl}_{2}, 4 \mathrm{CaCl}_{2}, 26 \mathrm{NaHCO}_{3}$, and 10 dextrose. For double whole-cell patch-clamp recordings from dentate gyrus $\mathrm{GFP}^{+}$basket cell (BC)-GC pairs, hippocampal slices were visualized with infrared (IR) illumination and differential interference contrast (DIC), using an Axioskop 2FS plus, equipped with fluorescence-IR Hamamatsu (Bridgewater, NJ) C2400-07E optics. A whole-cell recording (tight-seal, >1 G $\Omega$ ) with patch electrode $\left(3-5 \mathrm{M} \Omega\right.$ ) was initially obtained from a GFP ${ }^{+} \mathrm{BC}$ at the GC layer. Subsequently, the second whole-cell recording (tight seal, $>10 \mathrm{G} \Omega$ ) was made from a $\mathrm{GFP}^{+} \mathrm{GC}$. An extracellular stimulating electrode (bipolar tungsten; FHC, Bowdoinham, ME) was placed in the medial perforant fibers, the excitatory input to the dentate gyrus BCs and GCs. After recording, slices were placed in $4 \%$ paraformaldehyde in $0.1 \mathrm{M}$ phosphate buffer overnight and processed for BrdU staining. Postsynaptic GCs were recorded in voltage-clamp mode at $-70 \mathrm{mV}$ with high concentration intracellular $\mathrm{Cl}^{-}$solution, using an Axopatch 200B (Axon Instruments, Foster City, CA). Presynaptic BCs were recorded in current-clamp mode using an Axopatch 1D (Axon Instruments). Action potentials were evoked by current pulse ( $2 \mathrm{msec}, 1.5-2.5 \mathrm{nA})$ at a frequency of $0.1 \mathrm{~Hz}$. The input resistance and series resistance in postsynaptic pyramidal cells were monitored using prevoltage steps $(-2 \mathrm{mV}, 100$ msec). Series resistance ranged from 9 to $12 \mathrm{M} \Omega$. The unitary $\mathrm{GABA}_{\mathrm{A}}$ receptor IPSCs were filtered at $5 \mathrm{kHz}$ with a low-pass filter, digitized at a frequency of $10 \mathrm{kHz}$, and stored online using the pClamp8 system. For current-clamp mode, the intracellular solution contained (in $\mathrm{mM}$ ) 115 $\mathrm{K}^{+}$-gluconate, $7.5 \mathrm{~K}^{+} \mathrm{Cl}, 27.5 \mathrm{~K}^{+}$-methylsulfate, $10 \mathrm{HEPES}, 0.2 \mathrm{EGTA}$, $2 \mathrm{Mg}$-ATP, and 0.3 guanosine triphosphate, pH 7.4, $296 \mathrm{mOsm}$. For voltage-clamp recordings, the high concentration $\mathrm{Cl}^{-}$solution contained (in mM) $150 \mathrm{CsCl}, 10 \mathrm{HEPES}, 0.2$ EGTA, $2 \mathrm{Mg}$-ATP, and 0.3 guanosine triphosphate, $\mathrm{pH} 7.4,296 \mathrm{mOsm}$. A total of $0.1 \%$ rhodamine was also included to verify recorded BCs.

\section{Results}

To determine early new GABAergic neurons in the dentate gyrus of adult rats, the hippocampal sections of 10 -week-old rats treated 6 d previously with BrdU (group 1a) were colabeled with BrdU and $\mathrm{GAD}_{65}$, an isoform of glutamic acid decarboxylase that labels immature GABAergic cells (Dupuy and Houser, 1996; Huang et al., 1999). A considerable number of BrdU-labeled $\left(\mathrm{BrdU}^{+}\right)$cells were observed to be immunoreactive to $\mathrm{GAD}_{65}$ $\left(\mathrm{GAD}_{65}{ }^{+}-\mathrm{BrdU}^{+}\right)($Fig. $1 \mathrm{~A})$. The majority of $\mathrm{GAD}_{65}{ }^{+}-\mathrm{BrdU}^{+}$ cells had the morphological characteristics (irregular/triangular cells bodies) of GABAergic interneurons located in the subgranule zone. Subsequently, we stained these sections with TUC-4, which labels immature neurons (Minturn et al., 1995). We found that the $\mathrm{GAD}_{65}{ }^{+}-\mathrm{BrdU}^{+}$cells were colabeled by TUC-4 $\left(\mathrm{GAD}_{65}{ }^{+}-\mathrm{BrdU}^{+}-\mathrm{TUC}-4^{+}\right)$(Fig. $1 A$ ). These findings indicate that new GABAergic neurons are produced in the dentate gyrus of adult rats.

To determine the fate of these early new GABAergic cells, group $1 \mathrm{~b}$ animals were killed 6 weeks after the last BrdU injection. Hippocampal sections were double-labeled with BrdU and standard GABAergic neuronal markers, including PAV (Kosaka et al., 1985), CAL (Miettinen et al., 1992), and CCK (Kosaka et al., 1985). We found that some $\mathrm{BrdU}^{+}$cells were colabeled with PAV $\left(\mathrm{BrdU}^{+}-\mathrm{PAV}^{+}\right)$(Fig. $\left.1 \mathrm{~B}\right)$. Previous studies have shown that $\mathrm{PAV}^{+}$cells in the hippocampus are a particular subpopulation of GABAergic neurons, including BCs and axoaxonic cells (Kosaka et al., 1985; Freund and Buzsaki, 1996). Approximately 83\% of the $\mathrm{BrdU}^{+}-\mathrm{PAV}^{+}$cells in our study had the morphological characteristics of GABAergic BCs (Fig. 1B). Moreover, BrdU ${ }^{+}$cells were rarely seen to be positive for CAL (Fig. 1C) or CCK (Fig. $1 D)$. The data suggest that new GABAergic neurons in the dentate gyrus differentiate into BCs.

To further investigate newly generated GABAergic BCs, we expressed enhanced GFP in the hippocampus by infusion of pSFV $(p d)$-GFP infectious particles $\left(2 \mu \mathrm{l}\right.$ of $\left.>10^{9} \mathrm{U} / \mathrm{ml}\right)$. GFPexpressing neurons $\left(\mathrm{GFP}^{+}\right)$were observed over a $4 \mathrm{~mm}$ diffusion zone surrounding the injection sites $48 \mathrm{hr}$ after infection. GFP ${ }^{+}$ cell analysis showed that expression was highly neuron-specific (99\%), with glia cells showing little GFP expression (Fig. 1E). Most of the $\mathrm{GFP}^{+}$cells in the dentate gyrus $(\sim 82 \%)$ were located in the GC layer and expressed the morphological characteristics of GCs (i.e., a relatively small round cell body with dendrites extending toward the molecular layer). The remaining $\mathrm{GFP}^{+}$ cells $(\sim 18 \%)$ clearly had the morphological characteristics of GABAergic BCs (i.e., large-diameter fusiform cell somata with multipolar dendritic trees and profuse branching with long thin spines) (Fig. $1 E$ ).

We subsequently performed BrdU labeling in these sections. Using confocal laser-scanning microscopic analysis, we observed that $\sim 13 \%$ of the $\mathrm{GFP}^{+}$cells were clearly colabeled with BrdU $\left(\mathrm{GFP}^{+}-\mathrm{BrdU}^{+}\right)$and were located in the GC and subgranule cell layers of the dentate gyrus. We determined that these $\mathrm{GFP}^{+}-$ $\mathrm{BrdU}^{+}$cells were double-labeled neurons by performing 3D digital reconstruction (Fig. $1 F$ ). Based on morphological character- 
istics (large fusiform cell somata with multipolar dendrites) (Fig. $1 F$ ), $\sim 16 \%$ of the $\mathrm{GFP}^{+}-\mathrm{BrdU}^{+}$cells were identified as GABAergic BCs in the dentate gyrus ( $\mathrm{Ta}$ ble 1). In contrast to these findings in the dentate gyrus, $\mathrm{GFP}^{+}$cells were rarely colabeled with BrdU in the CA1 area (Fig. $1 G)$, indicating the absence of newborn neurons in the adult CA1 region of the hippocampus.

To determine further the early new GABAergic BCs in the adult dentate gyrus, we infected rats with pSFV $(p d)$-GFP vectors $6 \mathrm{~d}$ after the last BrdU injection (group 2 ). We found that $91 \pm 13 \%$ of the total $\mathrm{GFP}^{+}-\mathrm{BrdU}^{+}$cells ( $n=11$ rats) were immunoreactive to TUC-4, an early neural marker (Table 1). Approximately $16 \%$ of these TUC- $4^{+}$neurons were morphologically characterized as GABAergic BCs (Fig. $1 \mathrm{H}$ ). Moreover, staining of these sections with $\mathrm{GAD}_{65}$ revealed that $\sim 89 \% \mathrm{GAD}_{65}{ }^{+}$ cells were also immunoreactive to BrdU $\left(\mathrm{GFP}^{+}-\mathrm{GAD}_{65}{ }^{+}-\mathrm{BrdU}^{+}\right)$(Fig. 1I). In comparison with the mature interneurons labeled 6 weeks after the last BrdU injection (Fig. $1 F$ ), these immature GABAergic BCs had smaller fusiform cell soma $(\sim 20-30 \mu \mathrm{m})$ with smaller dendritic trees. These immature interneurons were rarely covered with spine structures, consistent with a previous study showing that mature spine and dendritic structures of central neurons are first evident 4 weeks after birth (Suzuki et al., 1997).

To establish whether the new GABAergic $\mathrm{BCs}$ in the adult dentate gyrus function as inhibitory neurons, we made use of double whole-cell patch-clamp recordings from monosynaptically connected dentate gyrus $\mathrm{GFP}^{+} \mathrm{BC}-\mathrm{GC}$ pairs. This approach was made possible by several factors: synaptically connected BC-GC pairs in the dentate gyrus were easily identified by morphological criteria (i.e., GFP expression) (Fig. 2A), BCs could be easily distinguished from GCs by their ability to generate high-frequency trains of action potentials during current injection (Fig. 2B) (Kraushaar and Jonas, 2000), and the amplitude of recorded unitary IPSCs evoked by intracellular stimulation of presynaptic BCs was large enough for analysis (Fig. 2C). The paired recording technique has the important advantage of being able to determine whether newly generated BCs form functional synapses onto GCs. In addition, staining the hippocampal sections with BrdU after the recordings permits comparisons of the physiological properties between $\mathrm{BrdU}^{+}$and $\mathrm{BrdU}^{-} \mathrm{BC}-\mathrm{GC}$ pairs (Table 2). We examined $169 \mathrm{BC}-\mathrm{GC}$ pairs from 22 animals and found that 16 of them had BCs labeled with BrdU (Fig. 2A). All measured parameters [mean latency, rise time (10-90\%), decay time constants $(\tau)$, peak amplitude, percentage of failures, and ratio of paired pulse depression (Fig. 2D)] in the $\mathrm{BrdU}^{+} \mathrm{BC}-\mathrm{GC}$ neurons.
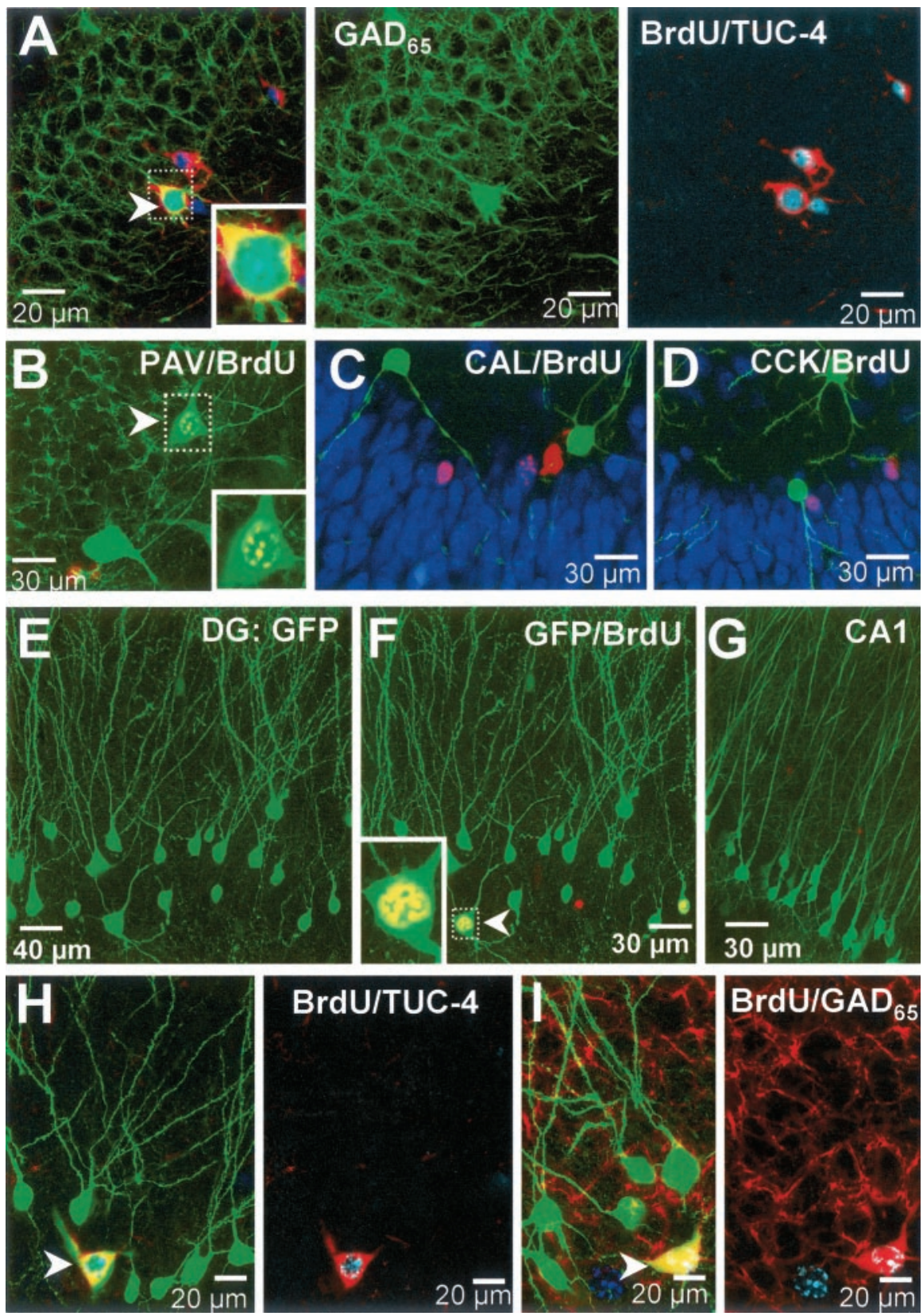

Figure 1. Generation of $\mathrm{GABAergic} B C s$ in the adult rat dentate gyrus. $A, A$ cell labeled with $\mathrm{GAD}_{65}$ (green), $\mathrm{BrdU}$ (blue), and TUC-4 (red). B, A PAV ${ }^{+}$cell (green) labeled with BrdU (red). C, No colabeling of BrdU (red) or NeuN (blue) with CAL (green). D, No colabeling of BrdU (red) or NeuN (blue) with CCK (green). E, Overview of a confocal laser-scanning image of GFP expression in a section of the dentate gyrus (DG). F, A GFP ${ }^{+}$BC (arrowhead) was colabeled with BrdU (red). G, No colabeling of GFP (green) with $\mathrm{BrdU}$ (red) was observed in the CA1 area. $\mathrm{H}_{,} \mathrm{A} \mathrm{GFP}{ }^{+}$cell labeled with BrdU (blue) and TUC-4 (red). I, A GFP ${ }^{+}$cell labeled with BrdU (blue) and $\mathrm{GAD}_{65}$ (red). The insets from the selected areas (dotted boxes) in $A, B$, and $F$ show the details of the double-labeled

pairs were statistically similar to those in the $\mathrm{BrdU}^{-} \mathrm{BC}-\mathrm{GC}$ pairs. Thus, the endogenous precursors can differentiate into functional BCs that establish reliable inhibitory synapses with the principle GCs in the dentate gyrus. Consistent with our hypothesis that these BCs are GABAergic inhibitory neurons, we showed that the unitary IPSCs were completely blocked by bath application of the $\mathrm{GABA}_{\mathrm{A}}$ receptor antagonist bicuculline $(10 \mu \mathrm{M})$ (Fig. 2C).

To determine whether these new BCs receive an excitatory synaptic input, we stimulated the medial perforant fibers in the dentate gyrus, and the EPSCs were recorded from BCs. Figure $2 E$ 
Table 1. Phenotypes of GFP ${ }^{+}$cells

\begin{tabular}{|c|c|c|c|c|}
\hline \multirow[b]{2}{*}{ Phenotypes of GFP ${ }^{+}$cells } & \multicolumn{2}{|l|}{$6 d$} & \multicolumn{2}{|c|}{6 weeks } \\
\hline & $B C s$ & GCs & $B C s$ & GCs \\
\hline $\mathrm{BrdU}^{+}-\mathrm{NeuN}^{+}-\mathrm{GFP}^{+}(n=12$ rats $)$ & 0 & 0 & 211 & 1708 \\
\hline $\mathrm{BrdU}^{+}-\mathrm{TUC}_{-} 4^{+}-\mathrm{GFP}^{+}(n=11$ rats $)$ & 226 & 1994 & 0 & 0 \\
\hline $\mathrm{BrdU}^{+}-\mathrm{GAD}_{65}{ }^{+}-\mathrm{GFP}^{+}(n=11$ rats $)$ & 238 & 0 & 0 & 0 \\
\hline
\end{tabular}

Cell numbers in the dentate gyrus were determined in rats infected with pSFV( $p d$ ) vector either $6 \mathrm{~d}$ or 6 weeks after their last BrdU injection. Immunostaining was performed $48 \mathrm{hr}$ after GFP expression. GFP ${ }^{+} \mathrm{BCs}$ and GCs were classified using fluorescence microscopy, according to morphological criteria (see Materials and Methods).

shows an example of recordings from a $\mathrm{GFP}^{+}-\mathrm{BrdU}^{+} \mathrm{BC}$ and an adjacent $\mathrm{BrdU}^{-} \mathrm{BC}$. The evoked EPSCs (single- vs paired-pulse stimulation) (Fig. $2 F$ ) in $\mathrm{BrdU}^{+} \mathrm{BCs}$ were analyzed and revealed properties similar to those recorded in $\mathrm{BrdU}^{-} \mathrm{BCs}$. These properties included large peak conductance, high reliability, fast rise of the evoked EPSCs, and significant facilitation of the paired-pulse responses (Table 2). These findings demonstrate that newly generated GABAergic BCs are functionally integrated into the dentate networks.

\section{Discussion}

Our findings demonstrate for the first time that functional inhibitory GABAergic BCs are newly recruited in the dentate gyrus of adult rats. With the use of mutant SFV vectors that preferentially introduce GFP into neurons, we directly analyzed the physiological properties of newly generated BCs. We thus show functional inhibitory synaptic connections between newly generated BCs and GCs in the dentate gyrus. New GABAergic BCs in the adult dentate gyrus were also confirmed by: (1) double staining of triangular, BC-like, BrdU ${ }^{+}$cells with PAV and (2) colabeling of $\mathrm{GAD}_{65}{ }^{+}-\mathrm{BrdU}^{+}$cells with TUC- 4 .

Two recent reports have shown that functional excitatory GCs are generated in the adult animal dentate gyrus. A first report by van Praag et al. (2002) established that retrovirus-GFP vectors label dividing cells in the dentate gyrus of the adult mouse, and demonstrated that newly generated cells receive functional synaptic inputs similar to those found in mature dentate excitatory GCs. A second report by Song et al. (2002) demonstrated that adult stem cells infected by retrovirus-GFP vectors retain the functional potentials shown in fetal tissues. Neurons derived from these stem cells possess axons and dendrites, are capable of firing action potentials, and are competent to form appropriate synapses with existing neurons. Both of these studies, however, focused exclusively on the production of excitatory GCs. By using mutant SFV vectors combined with double whole-cell patchclamp recordings, we have now revealed that functional inhibitory GABAergic BCs are also generated in the adult dentate gyrus.

GABAergic precursor cells are known to exist in the adult dentate gyrus, as demonstrated by the fact that isolated endoge-
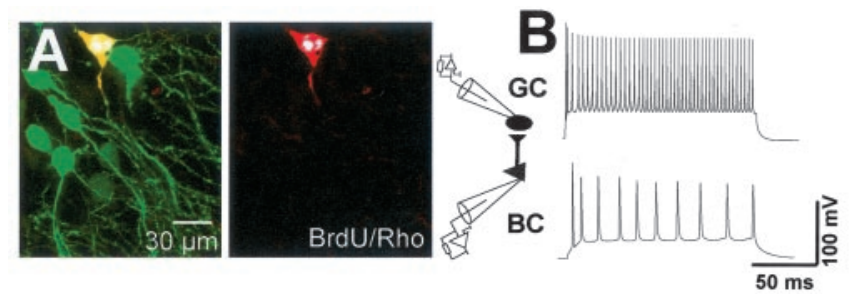

C

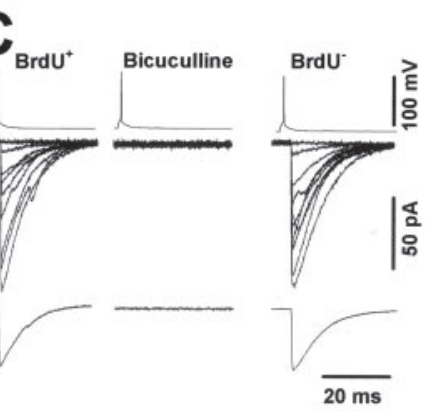

D
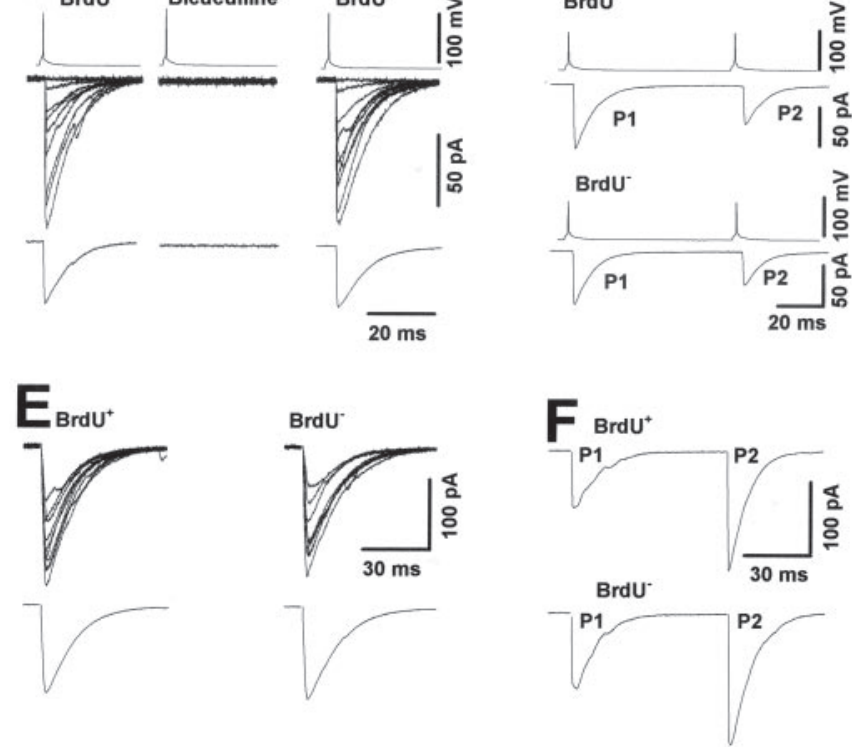

Figure 2. Newly generated BCs form appropriate synaptic transmission. A, A confocal laserscanning microscopic image of a GFP ${ }^{+}$(green) BC (arrowhead), labeled with BrdU (blue) and filled with rhodamine (Rho, red), that is synaptically connected with a GFP ${ }^{+} \mathrm{GC}$ (arrow). The schematic diagram illustrates a paired recording configuration from this $\mathrm{GFP}{ }^{+} \mathrm{BC}-\mathrm{GFP}{ }^{+} \mathrm{GC}$ pair in a hippocampal slice. $B$, Membrane potentials of this GFP ${ }^{+} \mathrm{BC}$ (top; resting membrane potential, $-76 \mathrm{mV}$ ) and the $\mathrm{GFP}^{+} \mathrm{GC}$ (bottom; resting membrane potential, $-74 \mathrm{mV}$ ), in response to depolarizing currents ( $200 \mathrm{msec}, 1.5 \mathrm{nA}$ ) recorded under current-clamp mode. $C$, Single action potentials from a BrdU ${ }^{+}$and a $\mathrm{BrdU}^{-}$presynaptic $\mathrm{BC}$ (top), and 10 consecutive single (middle) and averaged (bottom) unitary IPSCs at $-70 \mathrm{mV}$, from the paired GFP ${ }^{+} \mathrm{GC}$. Note that bath application of $10 \mu \mathrm{m}$ bicuculline (a $\mathrm{GABA}_{\mathrm{A}}$ receptor antagonist) blocked the unitary IPSCS. D, Single action potentials (top) from a BrdU ${ }^{+}$and a $\mathrm{BrdU}^{-}$presynaptic $B C$, and the averages (3 sweeps) of the paired-pulse unitary IPSCs (bottom). E, Ten consecutive single (middle) and averaged (bottom) EPSCs at $-70 \mathrm{mV}$, from a BrdU ${ }^{+} \mathrm{BC}$ and a $\mathrm{BrdU}^{-} \mathrm{BC}$, evoked by stimulation of the medial perforant fibers. $F$, Single paired-pulse EPSCs from a BrdU ${ }^{+} B C$ and $\mathrm{BrdU}^{-} \mathrm{BC}$ in the dentate gyrus.

nous progenitors from the adult mammalian hippocampus produce functional GABAergic inhibitory neurons in culture (Vicario-Abejon et al., 2000). Our discovery of the generation of inhibitory BCs in the adult dentate gyrus in situ provides compel-

Table 2. Physiological properties of synaptic transmission

\begin{tabular}{|c|c|c|c|c|}
\hline & \multicolumn{2}{|l|}{ Unitary IPSCs } & \multicolumn{2}{|l|}{ Evoked EPSCs } \\
\hline & $\mathrm{BrdU}^{+} \mathrm{BCs}(n=16)$ & $\mathrm{BrdU}^{-} \mathrm{BCs}(n=150)$ & $\mathrm{BrdU}^{+} \mathrm{BCs}(n=11)$ & $\mathrm{BrdU}^{-} \mathrm{BCs}(n=96)$ \\
\hline 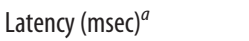 & $0.83 \pm 0.11$ & $0.77 \pm 0.06$ & $4.5 \pm 0.62$ & $5.2 \pm 0.13$ \\
\hline $10-90 \%$ rise time (msec) & $0.66 \pm 0.08$ & $0.67 \pm 0.03$ & $0.92 \pm 0.13$ & $0.95 \pm 0.04$ \\
\hline Decay $\tau(\mathrm{msec})^{b}$ & $4.41 \pm 0.54$ & $4.31 \pm 0.12$ & $13.6 \pm 2.7$ & $13.4 \pm 0.7$ \\
\hline Peak amplitude (pA) & $92.1 \pm 11.1$ & $101 \pm 4.6$ & $142 \pm 12.1$ & $149 \pm 4.3$ \\
\hline Failures (\%) & $15.2 \pm 2.4$ & $16.3 \pm 0.5$ & $8.4 \pm 1.1$ & $8.6 \pm 0.14$ \\
\hline \multicolumn{5}{|l|}{ Paired-pulse responses } \\
\hline (ratio of $\mathrm{P} 2 / \mathrm{P} 1)^{c}$ & $0.62 \pm 0.10$ & $0.68 \pm 0.04$ & $1.36 \pm 0.21$ & $1.32 \pm 0.04$ \\
\hline
\end{tabular}

${ }^{a}$ Latency of unitary IPSCS was estimated from the steepest point in the rise of the BC action potential to the onset of the IPSCs. The latency of EPSCS was measured from the starting point of stimulus artifact to the onset of the EPSCS. ${ }^{b}$ Decay time constants $(\tau)$ were measured based on monoexponential fit.

'Paired-pulse responses (paired-pulse depression of the unitary IPSCS and paired-pulse facilitation of the EPSCs) were evoked by paired-pulse stimulation at an interval of $50 \mathrm{msec}$. Values represent mean \pm SEM. 
ling evidence that the cultured GABAergic precursor cells have the same potential in vivo as in vitro. Because GABAergic inhibitory neurons are critical for the control of networks within the brain (Freund and Buzsaki, 1996), and because newborn neurons in adulthood replace neurons of the same class that have died (Magavi et al., 2000; Nottebohm, 2002), our results suggest a neuronal replacement strategy for the treatment of some neurological disorders and injuries including epilepsy, Alzheimer's disease, and stroke.

\section{References}

Cameron HA, McKay RD (2001) Adult neurogenesis produces a large pool of new granule cells in the dentate gyrus. J Comp Neurol 435:406-417.

Dupuy ST, Houser CR (1996) Prominent expression of two forms of glutamate decarboxylase in the embryonic and early postnatal rat hippocampal formation. J Neurosci 16:6919-6932.

Eriksson PS, Perfilieva E, Bjork-Eriksson T, Alborn AM, Nordborg C, Peterson DA, Gage FH (1998) Neurogenesis in the adult human hippocampus. Nat Med 4:1313-1317.

Freund EF, Buzsaki G (1996) Interneurons of the hippocampus. Hippocampus 6:347-470.

Gould E, Reeves AJ, Fallah M, Tanapat P, Gross CG, Fuchs E (1999) Hippocampal neurogenesis in adult old world primates. Proc Natl Acad Sci USA 96:5263-5267.

Huang ZJ, Kirkwood A, Pissorusso T, Porciatti V, Morales B, Bear MF, Maffei L, Tonegawa S (1999) BDNF regulates the maturation of inhibition and the critical period of plasticity in mouse visual cortex. Cell 98:739-755.

Kaplan MS, Hinds JW (1977) Neurogenesis in the adult rat: electron microscopic analysis of light radioautographs. Science 197:1092-1094.

Kornack DR, Rakic P (1999) Continuation of neurogenesis in the hippocampus of the adult macaque monkey. Proc Natl Acad Sci USA 96:5768-5773.

Kosaka T, Kosaka K, Tateishi K, Hamaoka Y, Yanaihara N, Wu JY, Hama K (1985) GABAergic neurons containing CCK-8-like and/or VIP-like immunoreactivities in the rat hippocampus and dentate gyrus. J Comp Neurol 239:420-430.

Kraushaar U, Jonas P (2000) Efficacy and stability of quantal GABA release at a hippocampal interneuron-principal neuron synapse. J Neurosci 20:5594-5607.
Lu YM, Mansuy IM, Kandel ER, Roder J (2000) Calcineurin-mediated LTD of GABAergic inhibition underlies the increased excitability of CA1 neurons associated with LTP. Neuron 26:197-205.

Lundstrom K, Schweitzer C, Richards JC, Ehrengruber MU, Jenck F, Mulhardt C (1999) Semliki Forest virus vectors for in vitro and in vivo applications. Gene Ther Mol Biol 4:23-31.

Lundstrom K, Rotmann D, Hermann D, Schneider EM, Ehrengruber MU (2001) Novel mutant Semliki Forest virus vectors: gene expression and localization studies in neuronal cells. Histochem Cell Biol 115:83-91.

Magavi SS, Leavitt BR, Macklis JD (2000) Induction of neurogenesis in the neocortex of adult mice. Nature 405:951-955.

Markakis E, Gage FH (1999) Adult-generated neurons in the dentate gyrus send axonal projections to the field CA3 and are surrounded by synaptic vesicles. J Comp Neurol 406:449-460.

Miettinen R, Gulyas AI, Baimbridge KG, Jacobowitz DM, Freund TF (1992) Calretinin is present in non-pyramidal cells of the rat hippocampus. II Co-existence with other calcium binding proteins and GABA. Neuroscience 48:29-43.

Miller DG, Adam MA, Miller AD (1990) Gene transfer by retrovirus occurs only in cells that are actively replicating at the time of infection. Mol Cell Biol 10:4239-4242.

Minturn JE, Fryer HJ, Geschwind DH, Hockfield S (1995) Toad-64, a gene expressed early in neuronal differentiation in the rat, is related to unc-33, a C. elegans gene involved in axon outgrowth. J Neurosci 15:6757-6766.

Nottebohm F (2002) Why are some neurons replaced in adult brain? J Neurosci 22:624-628.

Paton JA, Nottebohm F (1984) Neurons generated in the adult brain are recruited into functional circuits. Science 225:1046-1048.

Song HJ, Stevens CF, Gage FH (2002) Neural stem cells from adult hippocampus develop essential properties of functional CNS neurons. Nat Neurosci 5:438-445.

Suzuki F, Makiura Y, Guilhem D, Sorensen JC, Onteniente B (1997) Correlated axonal sprouting and dendritic spine formation during kainiteinduced neuronal morphogenesis in the dentate gyrus of adult mice. Exp Neurol 145:203-213.

van Praag H, Schlinder AF, Christle BR, Toni N, Palmer TD, Gage FH (2002) Functional neurogenesis in the adult hippocampus. Nature 415:1030-1034.

Vicario-Abejon C, Collin C, Tsoulfas P, McKay RD (2000) Hippocampal stem cells differentiate into excitatory and inhibitory neurons. Eur J Neurosci 12:677-688. 